\title{
Commentary: The cell without qualities?
}

\author{
Dagmar Kollmann, $\mathrm{MD}, \mathrm{PhD},{ }^{\mathrm{a}}$ and Konrad Hoetzenecker, $\mathrm{MD}, \mathrm{PhD}^{\mathrm{b}}$
}

\author{
From the ${ }^{\mathrm{a} D e p a r t m e n t}$ of Surgery, and ${ }^{\mathrm{b}}$ Division of Thoracic Surgery, Medical University of Vienna, Vienna, \\ Austria. \\ Disclosures: Authors have nothing to disclose with regard to commercial support. \\ Received for publication Sept 16, 2019; revisions received Sept 16, 2019; accepted for publication Sept 17, 2019; \\ available ahead of print Oct 3, 2019 \\ Address for reprints: Konrad Hoetzenecker, MD, PhD, Division of Thoracic Surgery, Medical University of \\ Vienna, Waehringer Guertel 18-20, 1090 Vienna, Austria (E-mail: konrad.hoetzenecker@meduniwien.ac.at). \\ J Thorac Cardiovasc Surg 2021;161:e93 \\ $0022-5223 / \$ 36.00$ \\ Copyright (C) 2019 by The American Association for Thoracic Surgery \\ https://doi.org/10.1016/j.jtcvs.2019.09.107
}

The Man Without Qualities, by Robert Musil, is considered one of the most significant novels of the 20th century. The main character, Ulrich, a young intellectual, is indifferent toward life and reality and lacks moral sense-he is referred to as a man of no qualities. Embedded in the complex social network of the sinking Austrian-Hungarian monarchy, Ulrich plays an important role in planning the 70th throne jubilee of Emperor Franz Joseph I.

The work published by Hsu and colleagues ${ }^{1}$ in this issue of the Journal strongly reminds us of Musil's novel. Hsu and colleagues $^{1}$ investigate the role of double-negative $\mathrm{T}$ cells in a model of ischemia and reperfusion of the lung. Double-negative $\mathrm{T}$ cells lack surface expression of both CD4 and CD8. They thus are deficient in the classic qualities discriminating $\mathrm{T}$ cells into helper and effector cells.

What is currently known about double-negative $\mathrm{T}$ cells? They account for fewer than $5 \%$ of the cells in the circulating $\mathrm{T}$ cell pool, but they play a key role in a variety of diseases, such as acute kidney injury, graft-versus-host disease, and type 1 diabetes. $^{2-4}$ The pathophysiologic effect of doublenegative $\mathrm{T}$ cells seems to vary with the surrounding. In some diseases, they promote an anti-inflammatory response. In others, such as ischemic stroke, double-negative $\mathrm{T}$ cells are a driving factor of neuroinflammation, and they exacerbate brain injury. ${ }^{5}$ In the examined model of ischemia-reperfusion injury, double-negative $\mathrm{T}$ cells possess anti-inflammatory properties and release large amounts of interleukin 10 .

Ischemia-reperfusion injury includes a plethora of signals, and through the years, our knowledge of the network of involved pathways has become more and more complex. ${ }^{6}$ Oxidative stress and shifts in the electrolyte compartments activate cell death signaling. This cellular damage subsequently triggers a proinflammatory cascade. Immune cells home to the site of injury and further amplify the damage. Ischemia-reperfusion injury clinically translates into primary graft dysfunction, which remains a major hazard for perioperative mortality. As a variety of immune cells modulate ischemia-reperfusion injury, a considerable number of animal studies targeting the immune reaction has been

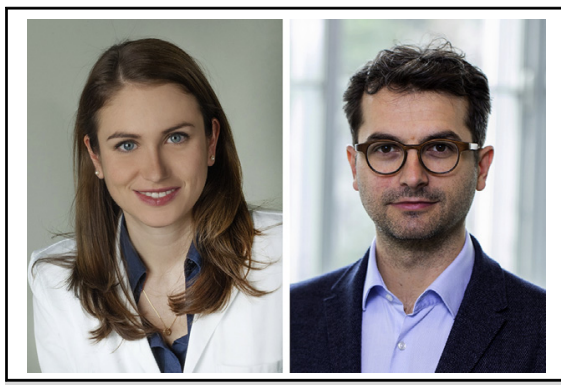

Dagmar Kollmann, MD, PhD (leff), and Konrad Hoetzenecker, MD, PhD (right)

Central Message

In order to qualify as a potential therapeutic target, a better understanding of the function of double-negative $\mathrm{T}$ cells during ischemiareperfusion injury is needed.

See Article page e81.

published. So far, all of these approaches have failed to translate into clinical lung transplantation.

The findings of $\mathrm{Hsu}$ and colleagues ${ }^{1}$ raise a number of questions, and the role of double-negative $\mathrm{T}$ cells in lung transplantation requires further investigation. What is the effect of $\mathrm{T}$ cell-depleting induction therapies on double-negative T cells? What is the role of these cells during acute cellular- or antibody-mediated rejection? Can they induce graft tolerance?

The work of Hsu and colleagues ${ }^{1}$ is extremely interesting and provides a fresh view on ischemia-reperfusion injury. Further efforts are needed, however, to unravel the qualities of double-negative T cells. Only then might they qualify as a potential novel therapeutic target.

\section{References}

1. Hsu J, Krishnan A, Lee SA, Dodd -OJM, Kim BS, Illei P, et al. CD3 ${ }^{+} \mathrm{CD} 4^{-} \mathrm{CD} 8$ double-negative $\alpha \beta$ T cells attenuate lung ischemia-reperfusion injury. J Thorac Cardiovasc Surg. 2021;161:e81-90.

2. Miyagawa F, Okiyama N, Villarroel V, Katz SI. Identification of $\mathrm{CD}^{+} \mathrm{CD}^{-} \mathrm{CD} 8$ $\mathrm{T}$ cells as potential regulatory cells in an experimental murine model of graft-versushost skin disease (GVHD). J Invest Dermatol. 2013;133:2538-45.

3. Martina MN, Noel S, Saxena A, Bandapalle S, Majithia R, Jie C, et al Double-negative $\alpha \beta$ T cells are early responders to AKI and are found in human kidney. J Am Soc Nephrol. 2016;27:1113-23.

4. Ford MS, Chen W, Wong S, Li C, Vanama R, Elford AR, et al. Peptide-activated double-negative $\mathrm{T}$ cells can prevent autoimmune type-1 diabetes development. Eur J Immunol. 2007;37:2234-41.

5. Meng H, Zhao H, Cao X, Hao J, Zhang H, Liu Y, et al. Double-negative T cells remarkably promote neuroinflammation after ischemic stroke. Proc Natl Acad Sci U S A. 2019;116:5558-63.

6. de Perrot M, Liu M, Waddell TK, Keshavjee S. Ischemia-reperfusion-induced lung injury. Am J Respir Crit Care Med. 2003;167:490-511. 